\title{
Measuring students' information skills through concept mapping
}

\author{
Maria Pinto ${ }^{1}$ \\ University of Granada
}

\author{
Anne-Vinciane Doucet; Andrés Fernández-Ramos
}

University of Granada

\begin{abstract}
This paper seeks to develop a methodology that will discover, specify and measure students' abilities and skills in creating concept maps. Because competencies are the key factor in higher education, the paper analyses the role of concept maps as a tool to diagnose and improve information analysis, synthesis, organisation and representation skills and competencies. We propose a methodology that enables these skills to be evaluated by observing, analysing and measuring the stages involved in creating a concept map: identification of the main and secondary subjects; subject codification by concepts; grading of concepts; and representation of the concepts and their relationships with labels. A case study using action-research methodology tests the usefulness of the methodology on a group of university students of Library and Information Science. The method proposed provides information on the strengths and weaknesses of the students' skills analysed, thus enabling their training to be improved by means of specific actions.
\end{abstract}

Keywords: Concept maps; Information organisation; Information literacy; Competencies; Skills.

\section{Introduction}

Information literacy (IL) entails learning the skills, competencies, knowledge and values to access, use and communicate information in any of its forms, in order to produce competent students and professionals trained in the routines of identifying, organising, evaluating and recording information sources appropriately and with the knowledge to process and produce their own information. Today, IL is inextricably associated with information practices and critical thinking in the information and communication technology environment [1]. The recent emergent importance of IL to the learning process is reflected in numerous publications [2-9].

Webber and Johnston [10] define information literacy as "the adoption of appropriate information behaviour to identify, through whatever channel or medium, information well fitted to information needs, leading to wise and ethical use of information in society". Information literacy forms the basis for lifelong learning [11]. It is

${ }^{1}$ Correspondence to: Maria Pinto, Faculty of Information Science, 18014 Granada, Spain. mpinto@ugr.es 


\section{Maria Pinto ; Anne-Vinciane Doucet ; Andrés Fernández-Ramos}

common to all disciplines, learning environments and levels of education. It enables learners to master content and extend their investigations, become more self-directed, and assume greater control over their own learning. In the last few years, the following associations of librarians have published the most important IL standards used in the design of tools and surveys for competency measurement.

\begin{tabular}{|c|c|c|c|c|}
\hline & $\begin{array}{r}\text { AASL } \\
\text { AECT [12] }\end{array}$ & SCONUL [13] & ACRL - ALA [14] & $\begin{array}{l}\text { ANZIIL \& CAUL } \\
{[15]}\end{array}$ \\
\hline $\begin{array}{l}\text { Efficient } \\
\text { management and } \\
\text { use of } \\
\text { information }\end{array}$ & $\begin{array}{l}\text { 3. The student } \\
\text { who is information } \\
\text { literate uses } \\
\text { information } \\
\text { accurately and } \\
\text { creatively. }\end{array}$ & $\begin{array}{l}\text { 6. The ability } \\
\text { to organise, apply } \\
\text { and communicate } \\
\text { information to } \\
\text { others in ways } \\
\text { appropriate to the } \\
\text { situation } \\
\quad 7 \text {. The ability } \\
\text { to synthesise and } \\
\text { build upon existing } \\
\text { information, } \\
\text { contributing to the } \\
\text { creation of new } \\
\text { knowledge }\end{array}$ & $\begin{array}{l}\text { 4. The } \\
\text { information literate } \\
\text { student, individually } \\
\text { or as a member of a } \\
\text { group, uses } \\
\text { information } \\
\text { effectively to } \\
\text { accomplish a specific } \\
\text { purpose. }\end{array}$ & $\begin{array}{l}\quad 4 . \\
\text { information literate } \\
\text { person manages } \\
\text { information } \\
\text { collected } \\
\text { generated. } \\
\quad 5 . \\
\text { information literate } \\
\text { person applies } \\
\text { prior and new } \\
\text { information to } \\
\text { construct new } \\
\text { concepts or create } \\
\text { new } \\
\text { understandings }\end{array}$ \\
\hline
\end{tabular}

Table 1. Extracts from IL standards referring to efficient information management

the American Association of School Librarians and the Association for Educational Communications and Technology [12];

- the Society of College, National and University Libraries [13];

- the Association of College and Research Libraries (ACRL) and the American Library Association (ALA) [14];

- the Australian and New Zealand Institute for Information Literacy (ANZIIL) and Council of

Australian University Librarians (CAUL) [15].Most of these standards refer to the domain of competencies related to the new ways of organising and representing information and propose observable indicators and outcomes.

For example, Standard 4 of the ACRL [14] IL standards mentions the importance of tools for organising content such as schemas, diagrams, concept maps: "The information literate student applies new and prior information to the planning and creation of a particular product or performance". Our professional and educational experience in this field confirms that mastery of these content organisation tools contributes to raising students' levels of maturity, and provides teachers with information on the student's capacity to organise, represent and structure content by establishing internal links between content and conferring coherence.

\section{Concept maps}

The hierarchical ranking and sequencing of concepts in an integrating reticular space known as a "concept map" appears to be closer to the way we represent mental content than the linear, sequential access typical of oral or written language. Various designations, while not synonymous, have been applied to the idea of the concept map: cognitive maps, proposed by Tolman [16] and understood as 'a graphical representation of the researcher's 


\section{Maria Pinto ; Anne-Vinciane Doucet ; Andrés Fernández-Ramos}

mental representation of a set of discursive representations expressed by a subject based on his or her own cognitive representations with regard to a specific object' [17]; mind maps, proposed by Buzan [18] and conceived as the graphical representation of a subject's reticular and creative thought from a central topic; semantic networks, proposed by Jonassen et al. [19] and conceptual maps, a term conceived by Novak and a group of graduates from Cornell University [20], as the method that visually represents events, concepts and ideas, and explains the relations between them. It is considered simultaneously as a learning strategy, a method to capture the most significant aspect of a topic, and a resource with which to represent a set of conceptual meanings included in a structure of propositions. Jonassen et al. [19] also state that the concept map is the visual representation of connected thoughts based on a given idea or topic. It can be used in the educational context to 'help learners to analyze and organize what they know or what they are learning'.

Concept maps represent an important component within the frame of heuristic and meaningful learning theory [21-24], focused on the learner's autonomous discovery and the lasting appropriation of concepts and propositions that favour the structuring of thought and its communication.

Concept maps are composed of networks of 'nodes' that represent concepts, and 'links' that accurately and meaningfully represent relations between these nodes. These links are labelled with terms chosen to identify the relation between the nodes. Concepts are arranged in hierarchical order from the most general and inclusive at the top, to the most specific at the bottom [25]. However, maps do not follow a set structure, and various types of internal organization exist: hierarchical, for dealing with primary and secondary concepts; spider diagrams, in which the term representing the main topic lies at the centre of the figure, with other terms arranged around it in the form of a web; sequential; and cyclical, where the information is arranged in a circular form. As educational tools, conceptual maps share the philosophy of hypertextual narration and may incorporate links to multimedia

\section{1. components in the form of hyperlinks. Design of concept maps}

Creating a concept map calls for creativity in organizing the structure of previously selected concepts and in connecting them by marks to indicate the type of relation between them [26]. To design the map, students were advised to follow a method comprising the stages outlined below [26-27]:

- Identify the important terms or concepts that you want to include on your map, through a studentgenerated list of concepts on a particular case study. Having read the text, you should be capable of selecting the important concepts required to answer the question: what is the main topic? Use circles to enclose only one important term or concept from the topic.

- Arrange concepts in a pattern that best represents the information using a hierarchical structure. You should decide the hierarchical order of the concepts by placing the most inclusive at the beginning of the list. Sub-concepts should then be selected and placed below each general concept. Not all students will coincide in their selection, as their previous knowledge and point of view will differ. You should review your list, adding more concepts if necessary.

- Use straight lines with arrows to link terms that are related. Each concept is defined by its relation to other concepts within the topic. This stage is particularly delicate as links are not always clear and you may be faced with alternatives about which you will have to make a decision

- Use labelling words along the lines to designate the relationship between two connected terms.

- Edit the map by reviewing and checking your work.

The skill involved in designing a concept map adds value to the efficiency of the student's active learning process, since the relations between meanings in the text are more clearly revealed in a two-dimensional structure than in a linear structure that can sometimes conceal these connections. 


\section{Maria Pinto ; Anne-Vinciane Doucet ; Andrés Fernández-Ramos}

\subsection{Use of concept maps}

Concept maps have been frequently used in the life sciences, but have also been applied in other disciplines such as political science, statistics, business, etc. Many studies have been conducted worldwide on concept maps. Novak [26, 28]) proposes the concept map as a useful tool for science education and as a facilitative tool in schools and corporations. Hsu and Hsieh [29] studied its effects in nursing education; Franca et al. [30] investigated its use in nutrition education; Roberts [31] in statistics education; Brandt et al. [32] in chemistry; Briscoe and LaMaster [33] and Kinchin [34] in biology instruction; Tumen and Tas sinar [35] use concept maps in language teaching; Sherratt and Schlabach [36] in reference and information services; Markha et al. [37] as a research and evaluation tool, concluding that this method affects student success positively. Chen et al. [38] demonstrated the importance of concept maps and their flexible applications in e-learning of a subject domain, bearing in mind that 'the graphical representation of domain knowledge can reduce the problems of information overload and learning disorientation for learners'. Trébucq and Noël [39] also provide evidence of their effectiveness, noting that NASA use concept maps as a support for preserving their knowledge.

In the area f education, concept maps can be used for a wide range of aims and functions. The following are particularly noteworthy $[27,40]$ :

- Instructional tool: to organise course content; to prepare specific lessons and to present material to students. In addition, they encourage text creation processes [41] and information reduction processes [42], both of which help to build a coherent structure of knowledge [40].

- Student learning tool: to learn course material; to take and organise class notes and to integrate material across different courses. Concept maps can encourage these skills by enhancing the acquisition and retention of macro-level ideas. Thus, learners concentrate on the most relevant macro-structure information from their learning topic [42]. In addition, concept maps contribute to the development of information skills, particularly those dealing with the organisation, representation and synthesis of information. Concept mapping fosters learning and understanding: as a follow-up strategy in learning from text it fulfils important functions of elaboration, reduction, coherence and metacognition. Concept maps foster elaboration processes, can enhance the acquisition and retention of macro-level ideas, encourage the building of a coherent structure of knowledge and support metacognitive processes [39].

- Assessment tool: to evaluate student learning and to assess changes and growth in the students' conceptual understanding as a result of instruction received in the course; to give student and instructor feedback, to evaluate aspects related to the comprehension of concepts, misconceptions requiring greater clarification and the pertinence of relations between concepts.

As well as a pedagogical tool for organising knowledge and thereby favouring meaningful learning, concept maps are also an instrument for evaluating students' learning and improving educational protocols. Despite these advantages, students run into difficulties because they do not receive adequate training and instruction in how to graphically represent and visualise information.

\section{Aim}

From our teaching experience on courses related to information analysis and representation, we can confirm that concept maps provide an excellent tool to teach comprehension, synthesis and representation of information. However, we have noted that students' previous training is inadequate in certain areas:

- Insufficient skills to understand and interpret graphic visualisation of information. Instruction appears to jump from the linear to the visual culture without adequate preparation.

- Limited knowledge about concept maps and their usefulness as a learning technique. Most new students do not study this topic in secondary education. 


\section{Maria Pinto ; Anne-Vinciane Doucet ; Andrés Fernández-Ramos}

- Lack of awareness about the value of maps as tools to develop students' information literacy; as key organisers of relevant information, maps provide the opportunity to acquire abilities and skills.

- Difficulties in both capturing and extracting the main concepts, and in mapping them graphically.

- Difficulties in tracing the links between concepts: some are omitted and others incorrect.

Given the importance of the ability to organise, analyse and synthesise information in higher education, and the usefulness of concept maps to organise information, the aim of this paper is to examine how students produce and use the concept map, both as a tool to organise and represent relevant information, and as a synoptic tool for learning. Likewise, from the information competencies perspective, the study aims to discover, specify and measure the abilities and skills that students use in the process of creating concept maps. By analysing how students perform each stage involved in this process, we can identify their strengths and weaknesses across a set of information skills:

- Comprehension and interpretation of texts, perceived through the way in which students capture the main idea and the structure of the text.

- Analysis and synthesis of the information, evaluated by analysing how students detect the most important paragraphs or sentences, their ability to translate them into concepts, and how they select the most important and the secondary concepts to establish a hierarchical structure.

- Representation of information, revealed in the way they organise concepts graphically by specifying how they are related to each other.

\section{Material and methods}

Content analysis methodology is used to observe and evaluate the skills and abilities students apply in the process of creating a concept map of a scientific article. By assessing the various processes and stages involved in the creation of a concept map we can also evaluate the students' information skills and abilities.

The scientific literature reports that concept maps can be evaluated from a range of perspectives, depending on the aspects to be evaluated: the creation of a concept map in itself, students' knowledge on a topic as revealed in the map, or through a text summary. Trébucq and Noël [38] outline various methods to carry out these evaluations on a different basis:

- analysis of the validity of the relations between concepts, according to whether they are correct or not, by systematising and quantifying the results [25].

- analysis of occurrences; frequency with which concepts occur is taken as a reference [44]

- content analysis of the relations between concepts. This method has been used by Trébucq and Noël [39] amongst others.

- semantic field analysis to evaluate the subject content of the maps. This method has been used by Trébucq and Noël [39] amongst others.

- analysis of the frequencies of nodes and labelled and non-labelled links, cross links etc., based on the work of Hilbert and Renkl [40].

For the purposes of this study, the action research methodology used by Pinto et al. [44] to evaluate document abstracts was adapted to evaluate concept maps. To gather the data we designed a template in which students were asked to record the way they carried out each stage in the process of creating a concept map of an article. A series of parameters and guidelines were established to evaluate and measure each stage and each process; a numerical value was established for each possible result; finally the results of the evaluations were analyzed. 


\section{Maria Pinto ; Anne-Vinciane Doucet ; Andrés Fernández-Ramos}

\subsection{The template}

The template designed to gather the data was based on one used to study document abstracts [45]. It was adapted to the stages involved in creating the concept maps and shortened for practical purposes. Students were asked to complete the following six sections of the template:

- Student details: name and course.

- Text evaluation: level of familiarity with the subject and difficulty of terminology. This information reveals students' perceptions of the complexity of the topic and allows us to analyse its possible influence on processing the information.

- Comprehension and interpretation of the text: identification of the general topic and structure of the text. Identifying the main topic of the text is key to its comprehension, since it is the first filter in distinguishing between truly important and superfluous information, and acts as a connecting hub for other ideas and concepts.

- Recognition of the text structure enables students to identify the type of documents they are dealing with, which will help them greatly in subsequent selection, organisational, and construction tasks.

- Analysis and synthesis: underlining the most important sentences, selection and hierarchical ordering of key concepts.

- Selecting the most important sentences allows students to recognise the parts of the text that contain most information, thus reducing the text that needs to be worked on.

- The representation of a text through keywords reveals the student's comprehension and analysis-and to a certain extent, synthesis and expression-capabilities.

- The hierarchical structuring of concepts from the most to the least important establishes levels of importance and dependence among the concepts.

- Creation of the map: selection of the main concept, to be used as the central node on the map; identification of other significant concepts; determining the type of relation between concepts by means of arrows and labels. These three steps guide the students and ensure that all of them follow the same procedure to create their maps.

- Difficulties and usefulness of the map: finally, students were asked to note down the difficulties they encountered in preparing the map, and their perceptions of its usefulness.

\subsection{Case studies}

Two groups of Library and Information Science students from the University of Granada (Spain) took part in the study, one group of first year undergraduates (20 students) from the Document Abstract and Indexing Techniques course, and the second group of final year undergraduates (34 students) from the Scientific Document Abstract course. Although these are compulsory core subjects taught in the classroom, electronic educational resources play an important part in the course; these resources include the portals Ciberabstracts ${ }^{2}$ [45], e-COMS ${ }^{3}$ $[46,47]$ and Alfin-EEES ${ }^{4}$. Both groups were given similar instruction in concept map preparation. Each group carried out the exercise, which lasted two hours, in separate classrooms (May 2008).

The selected text was entitled Lucha biológica contra las langostas: nuevas armas en una guerra milenaria (Biological control of locusts: New weapons for old enemies) published on 31 July 2006 by the FAO (Food and

2 Available at http://www.mariapinto.es/ciberabstracts

3 Available at http://www.mariapinto.es/e-coms

4 Available at http://www.mariapinto.es/alfineees 


\section{Maria Pinto ; Anne-Vinciane Doucet ; Andrés Fernández-Ramos}

Agriculture Organization of the United Nations) $)^{5}$. This text was chosen because it is short, bilingual and easily understood, and on a subject unrelated to library science to avoid giving an unfair advantage to the final year group.

The authors of this study identified the essential sentences and concepts by comparing their own conclusions, and defined the text structure and its main topic. A pre-test was carried out on a randomly selected case from each group. As a result of the pre-test, certain scales and the main topic were specified.

The authors reached a consensus on a set of scales to measure the results in order to evaluate the templates:

\begin{tabular}{|c|c|c|c|c|}
\hline Stage & Skills measured & Evaluation criterion & Case & Score \\
\hline \multirow{3}{*}{$\begin{array}{l}\text { Identification of } \\
\text { the main topic } \\
\text { in the text }\end{array}$} & \multirow{3}{*}{$\begin{array}{l}\text { Text } \\
\text { comprehension } \\
\text { and interpretation }\end{array}$} & \multirow{3}{*}{$\begin{array}{l}\text { Correct answer: } \\
\text { combination of the } \\
\text { terms "plague" } \\
\text { "locust" and "control" } \\
\text { (or synonym) }\end{array}$} & Correct identification & 1 \\
\hline & & & Partial identification & 0.5 \\
\hline & & & Not identified & 0 \\
\hline \multirow{4}{*}{$\begin{array}{l}\text { Identification of } \\
\text { the text } \\
\text { structure }\end{array}$} & \multirow{4}{*}{$\begin{array}{l}\text { Text } \\
\text { comprehension } \\
\text { and interpretation }\end{array}$} & \multirow{4}{*}{$\begin{array}{l}\text { Correct answer: } \\
\text { Introduction, } \\
\text { Development, } \\
\text { Conclusions }\end{array}$} & Correct identification & 1 \\
\hline & & & Most parts correctly identified & 0.75 \\
\hline & & & Some parts omitted & 0.5 \\
\hline & & & Not identified & 0 \\
\hline \multirow{2}{*}{$\begin{array}{l}\text { Underlining of } \\
\text { the most } \\
\text { important } \\
\text { sentences }\end{array}$} & \multirow{2}{*}{$\begin{array}{l}\text { Analysis and } \\
\text { synthesis of the } \\
\text { information }\end{array}$} & \multirow{2}{*}{$\begin{array}{l}\text { Of the } 65 \text { sentences in } \\
\text { the text } 16 \text { were } \\
\text { identified as important } \\
\text { and } 7 \text { as acceptable }\end{array}$} & $\begin{array}{l}\text { Thoroughness (number of correctly } \\
\text { underlined sentences/number of } \\
\text { important sentences in the text) }\end{array}$ & $\begin{array}{l}\text { Between } 0 \\
\text { and } 1\end{array}$ \\
\hline & & & $\begin{array}{l}\text { Accuracy (number of correctly } \\
\text { underlined sentences/number of } \\
\text { underlined sentences) }\end{array}$ & $\begin{array}{l}\text { Between } 0 \\
\text { and } 1\end{array}$ \\
\hline \multirow{2}{*}{$\begin{array}{l}\text { Extraction of } \\
\text { key concepts }\end{array}$} & \multirow{2}{*}{$\begin{array}{l}\text { Analysis and } \\
\text { synthesis of the } \\
\text { information }\end{array}$} & \multirow{2}{*}{$\begin{array}{l}\text { A total of } 9 \text { essential } \\
\text { and } 9 \text { important } \\
\text { concepts were } \\
\text { identified }\end{array}$} & $\begin{array}{l}\text { Thoroughness (number of correctly } \\
\text { underlined sentences/number of } \\
\text { important sentences in the text) }\end{array}$ & $\begin{array}{l}\text { Between } 0 \\
\text { and } 1\end{array}$ \\
\hline & & & $\begin{array}{l}\text { Accuracy (number of correctly } \\
\text { underlined sentences/number of } \\
\text { underlined sentences) }\end{array}$ & $\begin{array}{l}\text { Between } 0 \\
\text { and } 1\end{array}$ \\
\hline \multirow{3}{*}{$\begin{array}{l}\text { Hierarchical } \\
\text { ordering of key } \\
\text { concepts }\end{array}$} & \multirow{3}{*}{$\begin{array}{l}\text { Synthesis of the } \\
\text { information } \\
\text { Representation of } \\
\text { the information }\end{array}$} & \multirow{3}{*}{$\begin{array}{l}\text { The hierarchical } \\
\text { ordering of concepts } \\
\text { was scored according } \\
\text { to their importance } \\
\text { and their relation with } \\
\text { each other }\end{array}$} & Adequate & 1 \\
\hline & & & Borderline & 0.5 \\
\hline & & & Poor & 0 \\
\hline Selection of the & Synthesis of the & Correct answer: & Three concepts present & 1 \\
\hline
\end{tabular}

5 Available at http://www.fao.org/newsroom/es/focus/2006/1000345/index.html 


\section{Maria Pinto ; Anne-Vinciane Doucet ; Andrés Fernández-Ramos}

\begin{tabular}{|c|c|c|c|c|}
\hline \multirow[t]{3}{*}{$\begin{array}{l}\text { most important } \\
\text { concept }\end{array}$} & \multirow{3}{*}{$\begin{array}{l}\text { information } \\
\text { Representation of } \\
\text { the information }\end{array}$} & \multirow{3}{*}{$\begin{array}{l}\text { construction of the } \\
\text { main concept by } \\
\text { suitably relating the } \\
\text { terms "plague" } \\
\text { "locust" and "control" }\end{array}$} & Two concepts present & 0.75 \\
\hline & & & One concept present & 0.5 \\
\hline & & & No concept present & 0 \\
\hline \multirow{3}{*}{$\begin{array}{l}\text { Relation } \\
\text { between } \\
\text { concepts }\end{array}$} & \multirow{3}{*}{$\begin{array}{l}\text { Representation of } \\
\text { the information }\end{array}$} & \multirow{3}{*}{$\begin{array}{l}\text { Logical and coherent } \\
\text { association between } \\
\text { concepts was } \\
\text { evaluated }\end{array}$} & Correct & 1 \\
\hline & & & Partially correct & 0.5 \\
\hline & & & Incorrect & 0 \\
\hline \multirow{3}{*}{$\begin{array}{l}\text { Labelling of } \\
\text { relations }\end{array}$} & \multirow{3}{*}{$\begin{array}{l}\text { Synthesis of } \\
\text { information } \\
\text { Representation of } \\
\text { the information }\end{array}$} & \multirow{3}{*}{$\begin{array}{l}\text { Logical and coherent } \\
\text { labelling between } \\
\text { concepts was } \\
\text { evaluated }\end{array}$} & Correct & 1 \\
\hline & & & Partially correct & 0.5 \\
\hline & & & Incorrect & 0 \\
\hline \multirow{5}{*}{$\begin{array}{l}\text { Creation of the } \\
\text { concept map }\end{array}$} & \multirow{5}{*}{$\begin{array}{l}\text { Representation of } \\
\text { the information }\end{array}$} & \multirow{5}{*}{$\begin{array}{l}\text { An overall evaluation } \\
\text { was made taking into } \\
\text { account links, labels, } \\
\text { relations and concepts }\end{array}$} & $\begin{array}{l}\text { All the concepts were logically } \\
\text { related with labels. }\end{array}$ & 1 \\
\hline & & & $\begin{array}{l}\text { One incorrect element (missing } \\
\text { labels, unsuitable relations or } \\
\text { repeated concepts) }\end{array}$ & 0.75 \\
\hline & & & $\begin{array}{l}\text { Two incorrect elements (missing } \\
\text { labels and incorrect relation between } \\
\text { concepts) }\end{array}$ & 0.5 \\
\hline & & & $\begin{array}{l}\text { Many missing concepts, labels or } \\
\text { relations }\end{array}$ & 0.25 \\
\hline & & & Most elements omitted & 0 \\
\hline
\end{tabular}

Table 2. Scales to measure the results

\section{Results}

The text proved suitable for the purposes of the study, since first year and final year students were equally unfamiliar with the topic and shared the same difficulties with the terminology: very unfamiliar with the topic of the article (2.05 and 2.03 on a five-point scale, respectively) and few difficulties with the terminology ( 2.24 and 2.18 , respectively).

The results of the case study are reported for each of the stages in the concept map creation process, together with the evaluation of the end result of the process, the concept map. It should be noted that in some cases not all the students completed all the sections; the number of cases is therefore given for each stage. 


\section{Maria Pinto ; Anne-Vinciane Doucet ; Andrés Fernández-Ramos}

\subsection{Text comprehension}

There was a notable difference in the two groups' comprehension of the text; although both groups identified the main topic in a similar way, the final year students showed greater skill in identifying the text structure.

Identification of the main topic obtained average scores of 0.77 among first year students and 0.79 among final year students. Results for the two groups are therefore similar and can be regarded as acceptable: between $25 \%$ and $29 \%$ of students fully identified the main topic and around $60 \%$ noted two of the three key concepts, thus partially identifying the main topic.

\begin{tabular}{|l|l|l|}
\hline CASE (Evaluation) & FIRST YEAR $(\mathrm{N}=20)$ & FINAL YEAR $(\mathrm{N}=34)$ \\
\hline 1. All three terms (1) & $5(25 \%)$ & $10(29 \%)$ \\
\hline 2. Two terms $(0.75)$ & $12(60 \%)$ & $20(59 \%)$ \\
\hline 3. One term $(0.5)$ & $3(15 \%)$ & $4(12 \%)$ \\
\hline Average evaluation & 0.77 & 0.79 \\
\hline
\end{tabular}

Table 3. Results for identification of the main topic

A notable difference emerged between first year and final year students with respect to identification of the text structure. Whereas final year students obtained an acceptable score (0.59), first year students were unable to structure the text adequately: $57 \%$ structured it incorrectly and their average score was 0.29 . This suggests that the instruction received throughout the degree successfully increases students' capacity to identify text structures, a skill that the first year students had apparently not yet aquired.

\begin{tabular}{|l|l|l|}
\hline CASE (Evaluation) & FIRST YEAR $(\mathrm{N}=19)$ & FINAL YEAR $(\mathrm{N}=34)$ \\
\hline Correct $(1)$ & $2(11 \%)$ & $8(27 \%)$ \\
\hline Most parts correct $(0.75)$ & $2(11 \%)$ & $11(36 \%)$ \\
\hline Average $(0.5)$ & $4(21 \%)$ & $3(10 \%)$ \\
\hline Poor $(0)$ & $11(57 \%)$ & $8(27 \%)$ \\
\hline Average evaluation & 0.29 & 0.59 \\
\hline
\end{tabular}

Table 4. Results for identification of the text structure

\subsection{Analysis and synthesis}

The scores obtained in this section are fairly similar across the two groups, although slightly higher among final year students. The absence of significant differences between the two groups may result from the fact that final year students receive no more instruction in information analysis and synthesis than students at the end of their first year. The slightly higher scores obtained by the final year students may be due to their greater experience in reading texts.

Underlining the most important sentences in the text was evaluated according to the criteria of thoroughness (number of correctly underlined sentences divided by the number of important sentences in the text) and accuracy (number of correctly underlined sentences divided by the number of underlined sentences). Results for thoroughness were acceptable (63\% in the first year group and $66 \%$ in the final year group), and slightly less acceptable in terms of accuracy (53\% and 61\%, respectively), due to the large number of sentences underlined by both groups: an average of 27 sentences (40.8\% of the total) by the first year students and 25 (38\% of the total) by final year students. Final year students obtained slightly higher scores, but without major differences. 


\section{Maria Pinto ; Anne-Vinciane Doucet ; Andrés Fernández-Ramos}

Extraction of the key concepts was also evaluated according to thoroughness and accuracy. The terms the students suggested were first standardised, since in some cases different terms were proposed to refer to the same concept; hence 145 terms were finally identified from a total of 169. Results were again fairly similar between the two groups: for thoroughness, $65 \%$ in the first year group and $71 \%$ in the final year group; and for accuracy, 55\% in the first year group and $50 \%$ in the final year group. A notable difference was appreciated in the number of terms selected, with average values of $14(\mathrm{SD}=4.01)$ sentences in the first year group and $19(\mathrm{SD}=6.31)$ in the final year group.

Final year students obtained higher scores for thoroughness and lower scores for accuracy than the first year group; this result may be attributed to the fact that they identified a substantially higher number of concepts than the first year group.

The hierarchical ordering of key concepts was assessed on a scale with three values: adequate (1), borderline (0.5) and incorrect (0). Very similar results were obtained in the two groups, with average scores of 0.67 for the first year group and 0.72 for the final year group.

It should be noted that the template does not specify a particular schema to order the concepts. Students were therefore free to choose, and on the whole, both groups used diagrams based on arrows or hierarchical lists of terms.

In general, neither of the groups can be said to fully master information analysis and structuring skills.

\subsection{Creation of the concept map}

The end result of the process, the concept map, allowed us to analyse two particularly important aspects, as well as the overall evaluation: the selection and representation of the main concept; and the way in which links and labels were used to relate the nodes on the map.

Selection and representation of the main concept. The main concept, the control of locust plagues, should be represented by a combination of nodes and arrows so as to clearly express the idea that locusts can occur as a plague, and that people are striving to combat these plagues. The students' representation of this idea was evaluated on a scale of four values, assigned according to how correct and how complete their representation was.

\begin{tabular}{|l|l|l|}
\hline CASE (Evaluation) & FIRST YEAR (N=20) & FINAL YEAR (N=34) \\
\hline Correct (1) & $20 \%$ & $32 \%$ \\
\hline Partial (0.75) & $50 \%$ & $56 \%$ \\
\hline Poor (0.5) & $25 \%$ & $12 \%$ \\
\hline Incorrect (0) & $5 \%$ & $0 \%$ \\
\hline Average evaluation & 0.7 & 0.8 \\
\hline
\end{tabular}

Table 5. Evaluation of main node choice

Although broadly speaking these results are satisfactory, they reveal that both groups had difficulties in capturing and reflecting the main idea in its entirety, as most of the students only provided a partial represention of the main concept.

Both groups used the term "locusts" widely, although not always as the main node; differences were greater when the terms "plagues" and "control" were mentioned and related to the main node. First year students used the relation "locusts" + "plagues" more frequently, whereas in the final year group the combination "locusts" + "control" was recurrent, with "locusts" as the node and "control" as the link. 


\section{Maria Pinto ; Anne-Vinciane Doucet ; Andrés Fernández-Ramos}

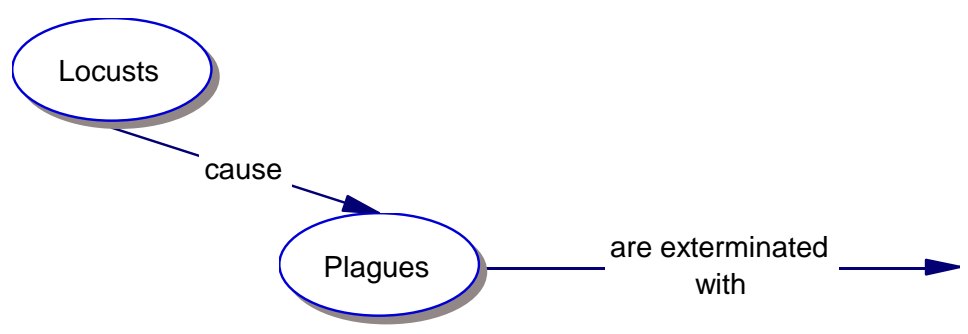

Illustration 1. First year. Label-node evaluation 1

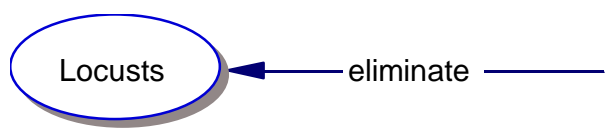

Illustration 2. First year. Label-node evaluation 0.75

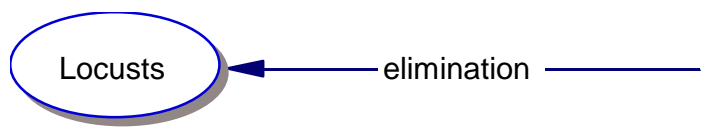

Illustration 3. Finalist. Label-node evaluation 0.75

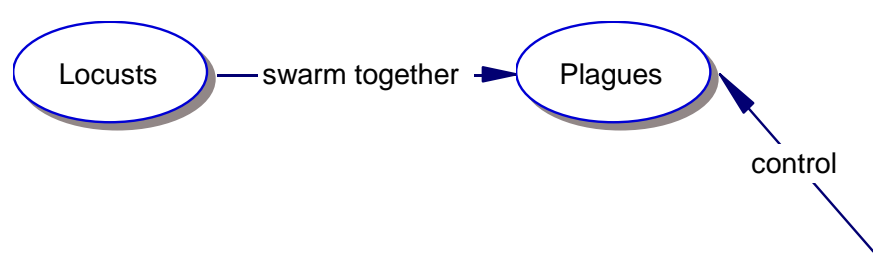

Illustration 4. Finalist. Label-node evaluation 1

The way this section of the exercise was carried out varied greatly: verbs and nouns were used indistinctly to represent an idea or concept, and a wide range of synonyms were given to refer to each element of the main concept, for example combat, control, exterminate, destroy, etc.

Analysis of the relation between nodes by means of links. Evaluation was based on whether the nodes on the map were associated with each other using links in a logical and coherent way.

\begin{tabular}{|l|l|l} 
CASE (Evaluation) & FIRST YEAR $(\mathrm{N}=20)$ & FINAL YEAR $(\mathrm{N}=34)$ \\
\hline
\end{tabular}




\section{Maria Pinto ; Anne-Vinciane Doucet ; Andrés Fernández-Ramos}

\begin{tabular}{|l|l|l|}
\hline Correct (1) & $60 \%$ & $68 \%$ \\
\hline Regular (0.5) & $40 \%$ & $32 \%$ \\
\hline Incorrect (0) & $0 \%$ & $0 \%$ \\
\hline Average evaluation & 0.8 & 0.9 \\
\hline
\end{tabular}

Table 6. Evaluation of the relation between concepts

The results show that both groups were fairly successful in relating the concepts (nodes) together, and no significant differences are detected between the two groups. This suggests that they are reasonably capable of establishing logical relations between a set of given concepts.

Analysis of labels. The labels on the links between nodes enable students to specify the relation between various concepts, thus giving the map a comprehensive meaning with the minimum of ambiguity. However, we noted that the first year students were less aware of the usefulness of labels, since they only labelled $66 \%$ of the links, compared to $94 \%$ labelled by the final year students. This discrepancy may stem from first year students' failure to understand the relation between concepts, or because they were unsure how to name the label appropriately.

It is worth noting that when students did use labels, they were reasonably successful in that they were able to create logical and meaningful propositions, slightly more so in the case of final year students who obtained an average score of 0.94 , compared to that of 0.8 obtained by the first year students.

\begin{tabular}{|l|l|c|}
\hline CASE (Evaluation) & FIRST YEAR (N=20) & $\begin{array}{c}\text { FINAL } \\
(\mathrm{N}=34)\end{array}$ \\
\hline Correct (1) & $65 \%$ & $82 \%$ \\
\hline Regular (0.5) & $30 \%$ & $18 \%$ \\
\hline Incorrect (0) & $5 \%$ & $0 \%$ \\
\hline Average evaluation & 0.8 & 0.9 \\
\hline
\end{tabular}

Table 7. Evaluation of label use

\subsection{Students' comments}

The students' assessment of this technique as a way of representing information is particularly useful since it reveals their perception of their own information capabilities and skills and complements our evaluations.

Both groups reported the selection and organisation of concepts as the most difficult tasks in creating the concept map, together with the problems inherent in the comprehension of texts on unfamiliar topics. The fact that students are more accustomed to a linear rather than a graphic way of working may largely explain their difficulties, since the switch from one to the other two involves a significant change in the way information is organised and represented.

The students noted many uses of concept maps, some of which were very important. They represent a powerful self-learning tool, particularly in virtual and semi-classroom-based environments. Many students also pointed to their use as a tool to graphically summarise information, creating settings for visual learning based on concept nodes rather than simple linear combinations of words. 


\section{Maria Pinto ; Anne-Vinciane Doucet ; Andrés Fernández-Ramos}

\subsection{Overall evaluation of the map}

The overall evaluation of the map was acceptable in both groups, although higher among final year students. This result was to be expected, since final year students have presumably received more instruction and possess a more fully developed range of information skills.

\begin{tabular}{|c|c|c|}
\hline CASE (Evaluation) & $\begin{array}{ll}\begin{array}{l}\text { FIRST } \\
(\mathrm{N}=20)\end{array} & \text { YEAR }\end{array}$ & $\begin{array}{c}\text { FINAL YEAR } \\
(\mathrm{N}=34)\end{array}$ \\
\hline Very good (1) & $10 \%$ & $32 \%$ \\
\hline Correct $(0.75)$ & $35 \%$ & $56 \%$ \\
\hline Regular (0.5) & $50 \%$ & $12 \%$ \\
\hline Poor $(0)$ & $5 \%$ & $0 . \%$ \\
\hline Average evaluation & 0.6 & 0.8 \\
\hline
\end{tabular}

Table 8. Overall evaluation of the concept maps

The various stages in the creation of the map reveal that on the whole, final year students obtained higher scores than first year students. The greatest differences emerged in the detection of the text structure, which is reflected in the end result, the concept map. The difference between the two groups can therefore be seen to lie in the students' skills in structuring information and identifying the text structure. The methodology used in this study has enabled us to determine precisely what the main differences were between the two groups as regards their information analysis and organisation skills, and point us in the right direction to address the training of these students in order to increase these skills.

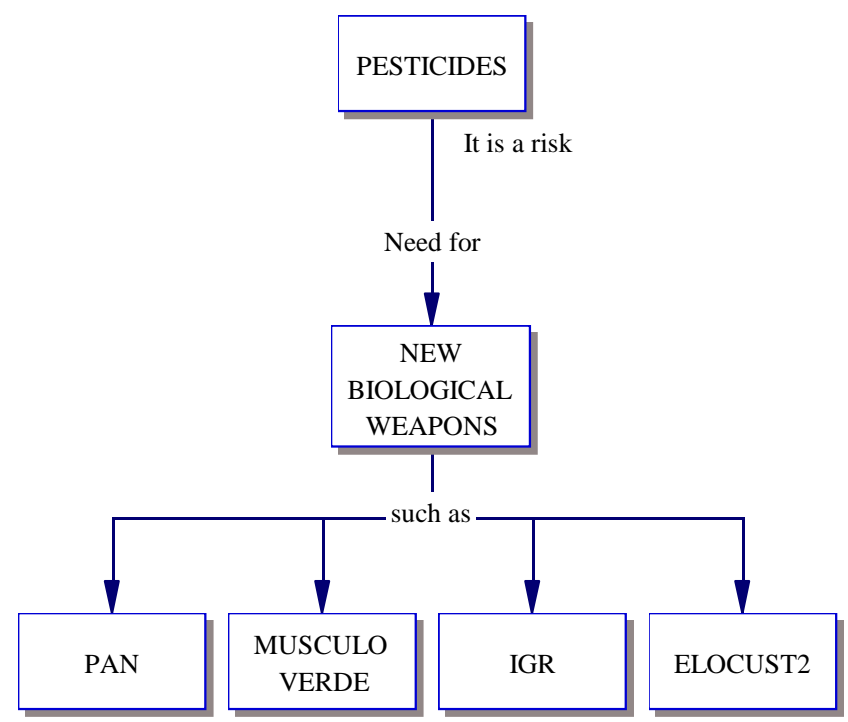

Illustration 5. First year. Average map. 


\section{Maria Pinto ; Anne-Vinciane Doucet ; Andrés Fernández-Ramos}

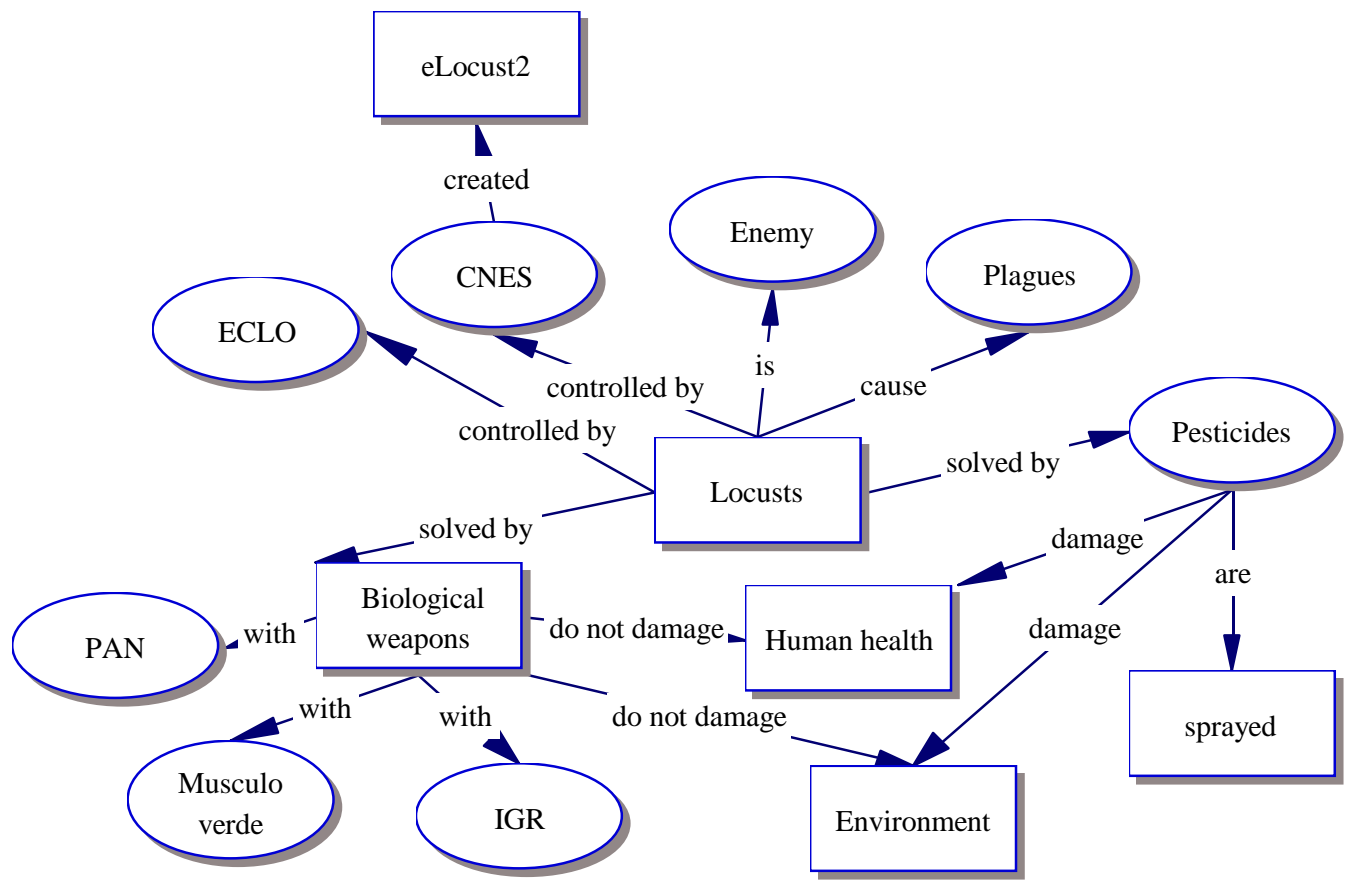

Illustration 6. First year. Good

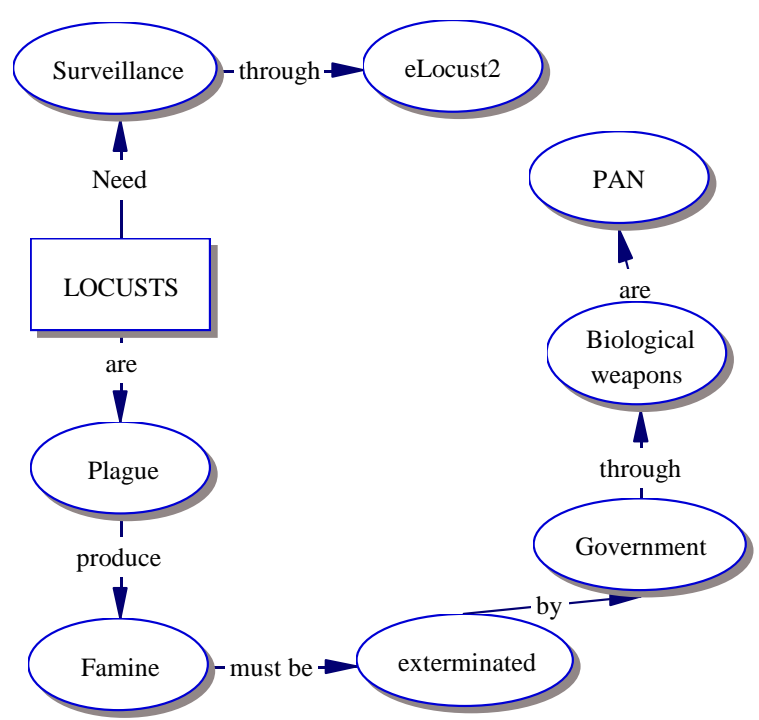

Illustration 7. Finalist. Average. 


\section{Maria Pinto ; Anne-Vinciane Doucet ; Andrés Fernández-Ramos}

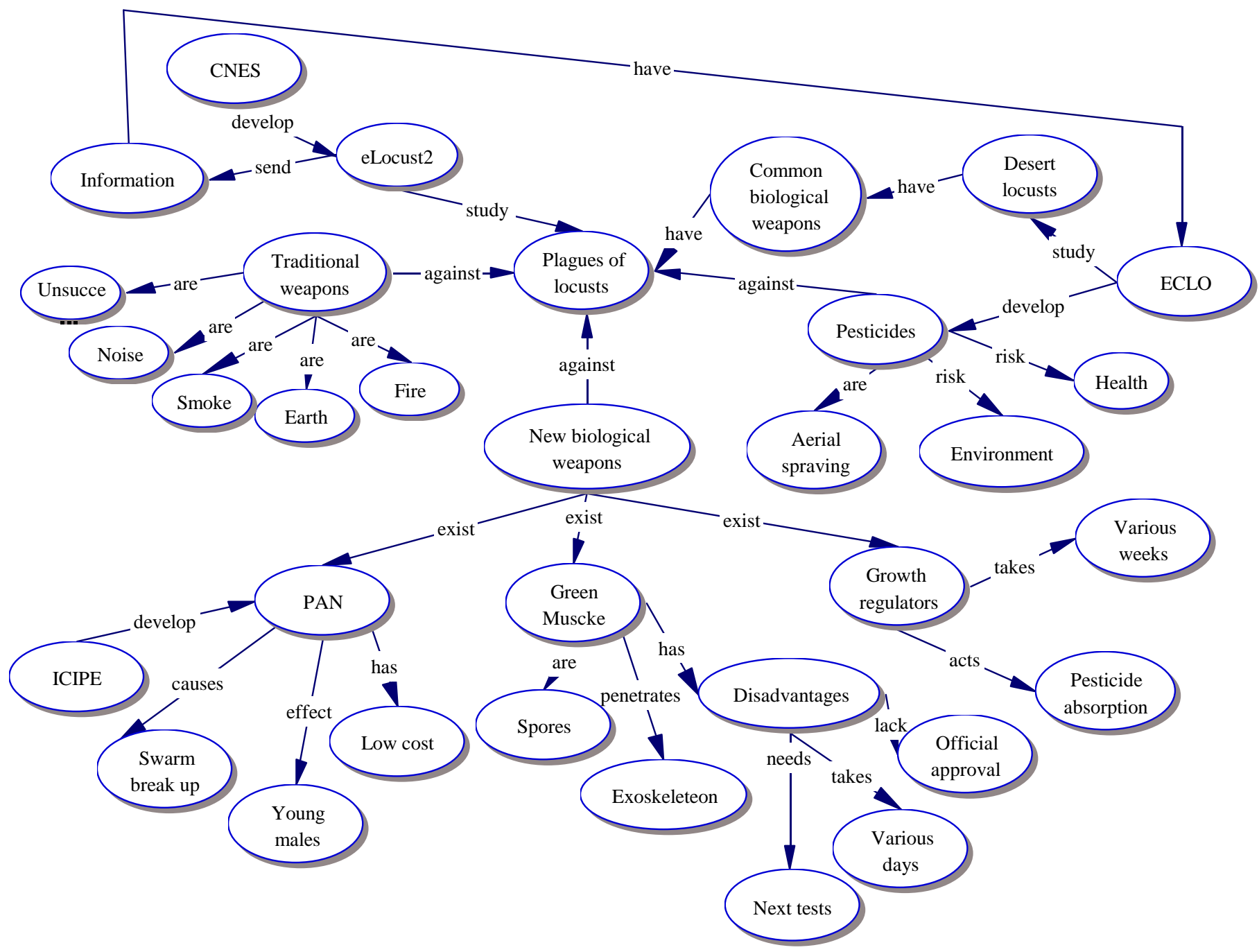

Illustration 8. Finalist. Well constructed map.

\subsection{Evaluation of information skills}

Although the overall results for both groups at all stages in the concept map preparation process can be considered good, certain differences between the stages emerge in relation to specific information skills.

Both groups demonstrated good text comprehension skills when detecting the main topic and capturing the general idea; however, a number of shortcomings -particularly among first year students- were noted when the students were required to examine the text more deeply, make interpretations and identify the text structure. Many students attempted to make the text "fit" the typical scientific article structure (introduction, aims, methodology, results and conclusions), without taking into account the type of text they had been given and consequently its structure. Students' instruction in this area should therefore be extended, with greater attention paid to understanding the nature of the text and its features, recognising the text structure, recognising the text sections and the units they are comprised of and recognising the thread of the argument and the relation between the text's 


\section{Maria Pinto ; Anne-Vinciane Doucet ; Andrés Fernández-Ramos}

component units. This can be done with exercises to identify different text types, organise markers, analyze sections or headings, and examine the typography of a text [48].

Acceptable results were obtained from the evaluation of information analysis and synthesis skills, although there was room for improvement. In general, students detected the key aspects, but were not so skilful at recognising what was superfluous in the text: they tended to attribute greater importance to superfluous elements. Finally, scores of the various stages regarding concept map creation (main node choice, relation between concepts and label use) display more than acceptable results. At this point, all students are competent enough.

\section{Conclusions}

Today we are witnessing a growing educational shift towards students' autonomous learning and the acquisition of both generic and specific skills and competencies. Information competencies are core generic competencies, particularly those related to the analysis, organisation and representation of information. Concept maps are an excellent methodological resource for these new learning models since on the one hand they favour the teaching and evaluation of information skills, and on the other, they help the student to understand, internalise and connect concepts through a reflective and critical learning process. Furthermore, they provide an extremely useful tool for generating and communicating information in today's knowledge society.

Through the methodology proposed in this study, we can detect the level of students' information skills in text comprehension, information analysis and synthesis and information representation by analysing the concept map creation process.

The tool proposed in this paper is flexible and can be adapted to evaluate students' learning since it enables us to guide them in the process of creating a concept map, and it provides a breakdown of their skills and competencies, which in turn simplifies the detection of the level of generic competencies students have acquired. Furthermore, as it is a general tool it can be applied to any type of text, and by focusing on the generic skills and competencies common to all domains it can also be applied to different spheres of knowledge. We can therefore claim that it is a useful tool for any teacher who is committed to training competencies, both generic and specific, within his or her educational domain, in this case with particular emphasis on the organisation and representation of information.

\section{References}

[1] C.S. Bruce, Information Literacy as a Catalyst for Educational Change: A Background Paper. White Paper prepared for UNESCO, the U.S. National Commission on Libraries and Information Science, and the National Forum on Information Literacy, for use at the Information Literacy Meeting of Experts (Prague, 2002).

[2] S. Andretta, Information Literacy: a practitioner's guide.(Chandos, Oxford, 2005).

[3] J. Elmborg, Critical information literacy: implications for instructional practice, Journal of Academic Librarianship, 32(2) (2008) 192-199.

[4] A. Lloyd, Information literacy landscapes: an emerging picture, Journal of Documentation 62(5) (2006) 570-583.

[5] C. Gibson (ed.), Student engagement and information literacy (Association of College and Research Libraries; American Library Association, Chicago, 2006).

[6] M. Lupton, The learning connection: information literacy and the student experience (Auslib Press, Adelaide, 2004).

[7] C.S. Bruce, The seven faces of information literacy (Auslib Press, Adelaide, 1997).

(C) The Author(s), 2009, Reprints and Permissions: http://www.sagepub.co.uk/journalsPermissions.nav 


\section{Maria Pinto ; Anne-Vinciane Doucet ; Andrés Fernández-Ramos}

[8] A. Martin and H. Rader (eds), Information and IT literacy: enabling learning in the 21st century (Facet Publishing, London, 2005).

[9] M. Pinto, D. Sales, INFOLITRANS: a model for the development of information competence for translators, Journal of Documentation 64(3) (2008) 413-437.

[10] S. Webber and B, Johnston, Information Literacy: definitions and models (2003) Available at: http://dis.shef.ac.uk/literacy/definitions.htm. (Accessed 16 July 2008).

[11] D. Ward, Revisioning information literacy for lifelong meaning, Journal of Academic Librarianship 32(4) (2006) 396-402.

[12] American Association of School Librarians (AASL) and Association for Educational Communications and Technology (AECT), Information Literacy Standards for student learning: standards and indicators (1998) Available at: http://slisweb.sjsu.edu/courses/250.loertscher/modelaasl.html. (Accessed 16 July 2008).

[13] Society of College, National and University Libraries, Information skills in higher education: a SCONUL position paper (1999). Available at: http://www.sconul.ac.uk/groups/information_literacy/papers/Seven_pillars2.pdf (Accessed 16 July 2008).

[14] Association of College and Research Libraries (ACRL) and American Library Association (ALA). Information Literacy Competency Standards for Higher Education, (ACRL, Chicago, 2000).

[15] Australian and New Zealand Institute for Information Literacy (ANZIIL) and Council of Australian University Librarians (CAUL), Australian and New Zealand Information Literacy Framework: Principles, Standards and Practice (Australian and New Zealand Institute for Information Literacy, Adelaide, 2004).

[16] EC Tolman, Cognitive maps in rats and men, The Psychological Review 55(4) (1948) 189-208.

[17] P. Cossette, M. Audet, Qu'est-ce qu'une carte cognitive? In: P. Cossette, Cartes Cognitives et Organisations(Presses de l'Université Laval and Paris, Québec, 1994).

[18] T. Buzan, Use your Head, (BBC Publications, London, 1974).

[19] D.H. Jonassen, C. Carr and H-P. Yueh, Computers as mindtools for engaging learners in critical thinking, TechTrends 43(2) (1998) 24-32.

[20] J.D. Novak, A theory of education (Cornell University Press, Ithaca, New York, 1977).

[21] D.P. Ausubel, A subsumption theory of meaningful verbal learning and retention, The Journal of General Psychology 66 (1962) 213-44.

[22] D.P. Ausubel, The psychology of meaningful verbal learning: an introduction of to school learning, (Grune \& Stratton, New York, 1963).

[23] D.P. Ausubel, Educational psychology: a cognitive view, (Holt, Rinehard and Winston, New York, 1968).

[24] D.P. Ausubel, J.D. Novak and H. Hanesian, Psicología educativa: un punto de vista cognitivo (Trillas, México, 1987).

[25] J.D. Novak and D.B. Gowin, Learning how to learn, (Cambridge University Press, New York, 1984).

[26] J.D. Novak, Learning, Creating, and Using knowledge: Concept Maps as Facilitative Tools in Schools and Corporations (Lawrence Erlbaum Associates, Mahweh, N.J, 1998).

[27] D.M. Zimmaro and J.M. Cawley, Concept map module. Schreyer Institute for Innovation in Learning (The Pennsylvania State University, 1998).

[28] J.D. Novak, Concept mapping: a useful tool for science education, Journal of Research in Science Teaching 27(10) (1990) 937-949.

[29] L. Hsu and S. Hsieh, Concept Maps as an Assessment Tool in a Nursing Course. Journal of Professional Nursing 21(3) (2005) 141-149.

[30] S. Franca, J. Francois d'Ivernois, C. Marchand, C. Haenni, J. Ybarra and A Golay, Evaluation of nutritional education using concept mapping, Patient Education and Counseling 52(2) (2004) 183-192 . 


\section{Maria Pinto ; Anne-Vinciane Doucet ; Andrés Fernández-Ramos}

[31] L. Roberts, Using concept maps to measure statistical understanding, International Journal of Mathematical Education in Science and Technology 30(5) (1999) 707-717.

[32] L. Brandt, J. Elen, J. Hellemans, L. Heerman, I. Couwenberg, L. Volckaert and H. Morisse, The impact of concept mapping and visualization on the learning of secondary school chemistry students, International Journal of Science Education 23(12) (2001) 1303-1313.

[33] C. Briscoe and S. LaMaster, Meaningful learning in college biology through concept mapping, The American Biology Teacher 53(4) (1991) 214-229.

[34] I.M. Kinchin, If concept mapping is so helpful to learn biologly Why aren't we all doing it? International Journal of Science Education 23(12) (2001) 1257-1269.

[35] S. Tumen and M. Taşpınar, The Effects of Concept Mapping on Students' Achievements in Language Teaching, 7th International Educational Technology Conference (IETC) (Near East University, 2007).

[36] C.S. Sherratt, M.L. Schlabach, The application of concept mapping in reference and information services, $R Q 30$ (1990) 60-69.

[37] K.M. Markha J. Mintzes and G.M. Jones, The concept map as a research and evaluation tool: further evidence of validity, Journal of Research in Science Teaching 31 (1994) 91-101.

[38] N. Chen, W.C. Kinshuk and H. Chen, Mining e-Learning domain concept map from academic articles, Computers \& Education 50(3) (2008) 1009-1021.

[39] S. Trébucq and C. Noël, Les cartes conceptuelles: un outil pédagogique pour un enseignement de la comptabilité intégrant l'éthique et la responsabilité, Comptabilité - Contrôle - Audit (2006) 5-37.

[40] T.S. Hilbert and A. Renkl, Concept mapping as a follow-up strategy to learning from texts: what characterizes good and poor mappers? Instructional Science 36(1) (2008) 53-73.

[41] C.E. Weinstein and R.E. Mayer, The teaching of learning strategies. In: C.M. Wittrock, Handbook of research in teaching (MacMillan Publishing Company, New York, 1986) pp. 315-27.

[42] C.A.Weaver and W. Kintsch, Expository text. In : R. Barr, M.L. Kamil, P.B. Mosenthal, et al. (Macmillan Publishing Company, New York, 1991) pp. 230-245.

[43] A.M. O’Donnell, D.F. Dansereau and R.H. Hall, Knowledge map as scaffolds for cognitive processing, Educational Psychology Review 14 (2002) 71-86.

[44] H.M. Michel, Les cartes cognitives du vote électronique: une approche exploratoire des systèmes de représentation des citoyens, Systèmes d'Information et Management, 10(1) (2005) 77-93.

[45] M. Pinto, A. Fernández-Ramos and A.-V. Doucet, Measuring students’s information skills throug abstracting, College and Research Libraries 69(2) (2008) 132-154.

[46] M. Pinto, Cyberabstracts: a portal on the subject of abstracting designed to improve information literacy skills, Journal of Information Science 34(5) (2008) 667-679.

[47] M. Pinto and A.-V. Doucet, An academic portal for higher education information literacy: the e-COMS initiative, Journal of Academic Librarianship 33(5) (2007) 604-611.

[48] M. Pinto and A.-V. Doucet, An educational resource for information literacy in higher education: functional and users analyses of the e-COMS academic portal, Scientometrics 72(2) (2007) 225-252.

[49] M. Pinto, A.-V. Doucet and A. Fernández-Ramos, The role of information competencies and skills in learning to abstract, Journal of Information Science 34(6) (2008) 799-815. 
APPENDIX

\begin{tabular}{|c|c|c|c|c|c|}
\hline \multicolumn{6}{|l|}{ STUDENT DETAILS } \\
\hline \multicolumn{6}{|l|}{ Full name } \\
\hline \multicolumn{6}{|l|}{ Degree } \\
\hline \multicolumn{6}{|l|}{ Course } \\
\hline \multicolumn{6}{|l|}{ TEXT EVALUATION } \\
\hline $\begin{array}{l}\text { How familiar are you with the } \\
\text { topic the text deals with? }\end{array}$ & Very & Fairly & A little & Very little & Not at all \\
\hline \multirow{2}{*}{$\begin{array}{l}\text { Did you find the terminology } \\
\text { complicated? }\end{array}$} & Very & Fairly & A little & Very little & Not at all \\
\hline & & & & & \\
\hline \multicolumn{6}{|c|}{ COMPREHENSION AND INTERPRETATION OF THE TEXT } \\
\hline \multicolumn{2}{|c|}{ Identify the main topic (in a couple of words) } & & & & \\
\hline \multicolumn{2}{|c|}{$\begin{array}{l}\text { Identify the text structure (for example, in a } \\
\text { scientific text: introduction, aims, methodology, } \\
\text { results and conclusions) }\end{array}$} & \multicolumn{4}{|c|}{ Mark in the text } \\
\hline \multicolumn{6}{|c|}{ ANALYSIS AND SYNTHESIS } \\
\hline \multicolumn{2}{|c|}{ Underline the most important sentences } & \multicolumn{4}{|c|}{ Mark in the text } \\
\hline \multicolumn{2}{|c|}{$\begin{array}{l}\text { Identify key concepts from the most important } \\
\text { sentences (between } 10 \text { and } 20 \text { concepts) }\end{array}$} & & & & \\
\hline \multicolumn{2}{|c|}{$\begin{array}{l}\text { Order the key concepts (from more to less } \\
\text { important) and relate them to each other }\end{array}$} & & & & \\
\hline \multicolumn{6}{|c|}{ CREATION OF THE CONCEPT MAP } \\
\hline \multicolumn{6}{|l|}{ Select the most important concept } \\
\hline \multicolumn{6}{|c|}{ Relate the concepts to each other using arrows } \\
\hline \multicolumn{6}{|c|}{$\begin{array}{l}\text { Label the arrows with prepositions or propositions } \\
\text { that explain the relation between the concepts }\end{array}$} \\
\hline \multicolumn{6}{|c|}{ DIFFICULTIES AND USEFULNESS } \\
\hline \multicolumn{6}{|c|}{ What difficulties did you come across in creating the concept map? } \\
\hline What use do you think concept & s have as part o & f your lea & experien & & \\
\hline
\end{tabular}

